\title{
Critical thermal maxima and minima of the platyfish Xiphophorus maculatus Günther (Poecillidae, Cyprinodontiformes) - a tropical species of ornamental freshwater fish
}

\author{
Viviane Prodocimo ${ }^{1}$ \\ Carolina Arruda Freire ${ }^{1}$
}

\begin{abstract}
Temperature as an environmental factor has been a frequent subject of study, since it affects either directly or indirectly all living organisms. The determination of thermal limits (critical thermal minima $-\mathrm{CT}_{\min }$ and maxima $-\mathrm{CT}_{\max }$ ) for the tropical ornamental freshwater teleost Xiphophorus maculatus Günther, 1866 (platyfish) was performed after their acclimation to the following temperatures: 15,20 , 25 , and $30^{\circ} \mathrm{C}$, for seven days. After this period, the water temperature was elevated or reduced at a rate of $0.125^{\circ} \mathrm{C} / \mathrm{min}$ until $\mathrm{CT}_{\max }$ and $\mathrm{CT}_{\min }$ could be determined as the temperature at which $50 \%$ of the animals had lost equilibrium. Mean values for $\mathrm{CT}_{\max }$ and $\mathrm{CT}_{\min }$ for the acclimation temperatures of $15,20,25$, and $30^{\circ} \mathrm{C}$ were respectively: $39.8,39.8,40.4,41.5^{\circ} \mathrm{C}\left(\mathrm{CT}_{\max }\right)$, and $9.6,12.8,13.1,16.0^{\circ} \mathrm{C}\left(\mathrm{CT}_{\min }\right) . \mathrm{CT}_{\max }$ and $\mathrm{CT}_{\min }$ for $X$. maculatus were thus affected by acclimation temperature. This tropical species is more heat- than cold- tolerant and would not resist the typical low winter temperatures of southern Brazil. Platyfish can adapt to natural environments in regions of mean annual temperatures around $20-25^{\circ} \mathrm{C}$ or be kept in aquaria with other ornamental species that accordingly prefer this temperature range.

KEY WORDS. Xiphophorus maculatus, temperature, critical thermal maxima and minima, acclimation, platyfish
\end{abstract}

The relevance of the temperature as an environmental parameter has been thoroughly evidenced in the literature. It is one of the most studied ecological factors, not only because it is relatively easy to measure, but also because it is a limiting factor for the chemical reactions on which vital functions are based (EvANS 1993; POUGH et al. 1996; SCHMIDT-NIELSEN 1997). The effects of temperature can be observed on animal movement, feeding, growth, and reproduction, among other functions (FERNANDES \& RANTIN 1986a; BENFEY et al. 1997).

Fish are certainly no exception to the rule and their physiology is strongly affected by the temperature. In nature, fish occur along a relatively wide range of temperatures, from seawater freezing point $\left(-1.8^{\circ} \mathrm{C}\right)$ until $37^{\circ} \mathrm{C}$ or even higher temperatures, such as $40^{\circ} \mathrm{C}$ or $41^{\circ} \mathrm{C}$ (HUTCHISON 1961; SCHMIDT-NIELSEN 1997), although obviously their occurrence in both extremes is relatively low (DOUDOROFF 1942), and most species live under intermediate thermal regimes. The range of temperatures in the natural environment of animals living in different geographical areas obviously lead to differences in the temperatures they can tolerate experimentally (BRETT 1956), not only for fish but also for other ectothermic organisms.

1) Departamento de Fisiologia, Setor de Ciências Biológicas, Universidade Federal do Paraná. Centro Politécnico, 81531-990 Curitiba, Paraná, Brasil. 
The concept of critical temperature, maximum and minimum, has been introduced by COWLES \& BOGERT (1944), when trying to standardize thermal tolerance assays of several animals. It has been defined as the temperature at which locomotor activity becomes disorganized, and the animals lose their capacity to escape from possibly lethal conditions. The procedure of thermal acclimation is important in order to determine critical temperatures. Acclimation influences the thermal tolerance of an organism, especially before a critical temperature test, generating different results for animals which were acclimated to the temperature of the natural environment when compared to others acclimated to either lower or higher temperatures (HUTCHISON 1961; LUTTERSCHMIDT \& HUTCHISON 1997b).

Although many studies have been conducted on the effect of temperature on temperate fish, less data has been gathered about tropical and subtropical species (RIETZLER et al. 1980). Low temperatures can be a problem for fish of subtropical latitudes. In shallow lakes and rivers the fish can be exposed to significant seasonal variations in temperature, which can reach critically low values during the winter months (BARRIONUEVO \& FERNANDES 1995).

In order to grow ornamental species, it is crucial to know about their behavioral and physiological characteristics, and how these characteristics respond to environmental parameters such as temperature. The platyfish Xiphophorus maculatus Günther, 1866 belongs to the family Poecillidae. These small freshwater fish (approximately $5 \mathrm{~cm}$ ), are viviparous, present variable body coloration (JORDAN 1963), and are distributed from Southern United States down to South America (NELSON 1994). In the River Papaloapan, Mexico, its natural habitat, temperature is of approximately $23.8^{\circ} \mathrm{C}$ (GoHM 1972). The reasons for keeping X. maculatus as an ornamental fish are that they are non-aggressive, can be easily grown, and can be obtained in a variety of colors.

There are no available data on the thermal tolerance of $X$. maculatus, and due to its worldwide relevance as an ornamental fish, it is important to determine its thermal limits. The determination of its thermal limits will provide the ideal conditions with respect to this important environmental parameter for the maintenance of this species in captivity, either isolated or together with other species.

\section{MATERIAL AND METHODS}

\section{Thermal acclimation}

Specimens of Xiphophorus maculatus were purchased from an aquarium shop in Curitiba, Paraná, Brazil, and were taken to the laboratory of Comparative Physiology of Osmoregulation, Federal University of Paraná, where they were maintained in a $30-\mathrm{L}$ aquarium filled with filtered tap water at room temperature $\left(\sim 20-25^{\circ} \mathrm{C}\right)$ and under constant aeration. Water $\mathrm{pH}$ was maintained at $7 \pm 0.5$, eventually corrected using commercially available solution (Labcon) specific for $\mathrm{pH}$ control of aquarium water. During the whole period of thermal acclimation the fish were fed daily with floculated fish food (Alcon) indicated for ornamental fish and feeding was interrupted two days before, and during the experiments. The experiments were conducted between February and May 1999, always during the day, under natural light. 
Specimens measuring $3.6 \pm 0.9 \mathrm{~cm}$ (mean $\pm \mathrm{SD}$ ), were divided in groups of 10 individuals, and then transferred to an acclimation chamber containing $12 \mathrm{~L}$ of filtered tap water, under constant aeration, and supplied with a device that allowed gradual increases or decreases in water temperature. The acclimation temperatures were: $15,20,25$, and $30^{\circ} \mathrm{C}$. For each acclimation temperature, four independent groups of fish were used. The fish were introduced into the acclimation chamber, at about $25^{\circ} \mathrm{C}$ (room temperature), and the temperature was gradually modified towards the acclimation value (rate of approximately $1.4^{\circ} \mathrm{C} / \mathrm{h}$ ). This acclimation temperature was then maintained for seven days.

\section{Determination of thermal tolerance}

After the acclimation to a given temperature, water temperature was increased or decreased at a rate of approximately $1^{\circ} \mathrm{C}$ for each 8 minutes (rate of $0.125^{\circ} \mathrm{C} / \mathrm{min}$ ), and the number of animals within the group of 10 animals displaying: 1) motor disorganization, 2) loss of response to stimuli, 3) loss of equilibrium, and 4) respiratory arrest was counted, as temperature was modified. The loss of response to stimuli was observed by mechanical stimulation using a glass rod. The other behaviors were accounted by observation of their movement: motor disorganization, when the swimming pattern was greatly modified with respect to their normal condition; loss of equilibrium, when the fish turned on their sides while swimming; respiratory arrest, when their operculum movements ceased.

Thermal limits (critical thermal) for a given acclimation temperature were considered as the temperature at which $50 \%$ (i.e., five animals) had lost equilibrium (Method of Critical Temperature, HuTCHISON 1961). Thermal limits were the mean values obtained for the two independent groups of 10 fish tested for the same experimental condition. The onset of the display of each behavior was considered as the temperature at which the first animal in the group presented that behavior.

\section{RESULTS}

Critical thermal maxima $\left(\mathrm{CT}_{\max }\right)$ and minima $\left(\mathrm{CT}_{\min }\right)$ are displayed in figure 1. $\mathrm{CT}_{\max }$ and $\mathrm{CT}_{\min }$ for Xiphophorus maculatus were both affected by the acclimation temperature (AT). Tolerance to temperature increase was slightly more pronounced in the groups acclimated to $25^{\circ} \mathrm{C}$ and $30^{\circ} \mathrm{C}$ than in the groups acclimated to $15^{\circ} \mathrm{C}$ and $20^{\circ} \mathrm{C}$ (Fig. 1). Accordingly the tolerance to temperature decrease was slightly more pronounced in the groups acclimated to $15^{\circ} \mathrm{C}$ and $20^{\circ} \mathrm{C}$ than in groups acclimated to $25^{\circ} \mathrm{C}$ and $30^{\circ} \mathrm{C}$. In both cases, there was a direct relationship between acclimation temperature and critical thermal limits (Fig. 1), with high regression coefficients: $\mathrm{r}^{2}=0.85$ for $\mathrm{CT}_{\max }$ and 0.92 for $\mathrm{CT}_{\min }$. Furthermore, the angular coefficient $(a=\operatorname{tg} \alpha)$ for the regression line $(y=a x+b)$ representing acclimation temperatures is $1\left(\alpha=45^{\circ}\right)$, for the $\mathrm{CT}_{\max }$ line is 0.12 , and for $\mathrm{CT}_{\min } 0.40$. As a consequence, despite the direct relationship (both coefficients are positive) between $\mathrm{CT}_{\max }$ and $\mathrm{CT}_{\min }$ and the acclimation temperatures, $\mathrm{CT}_{\max }$ and $\mathrm{CT}_{\min }$ varied, although not as much as the acclimation temperatures did. An acclimation temperature of $35^{\circ} \mathrm{C}$ was attempted, but only four animals out of the 10 specimens used for one of the groups survived the acclimation period (seven days). Thus, it was not possible to determine $\mathrm{CT}_{\max }$ and $\mathrm{CT}_{\min }$ for this temperature of acclimation. 


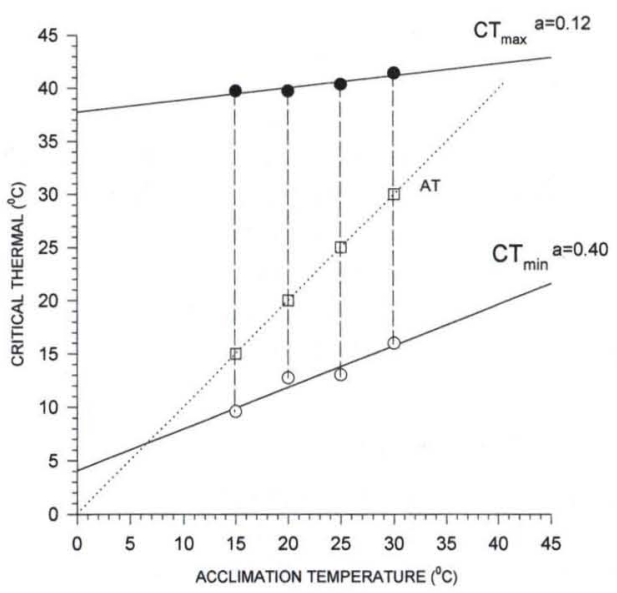

Fig. 1. Linear regression between the average critical thermal maxima $\left(C T_{\max }, \bullet, r^{2}=0.85\right)$ and critical thermal minima $\left(C \mathrm{CT}_{\min }, \mathrm{O}, \mathrm{r}^{2}=0.92\right)$ and the acclimation temperature. A regression line of the values of acclimation temperature (AT) against themselves is also indicated on the graph in order to evidence the relationship between AT values and the critical thermal limits determined for $X$. maculatus. The values of critical thermal limits are: acclimation temperature $(\mathrm{AT})=15^{\circ} \mathrm{C}, \mathrm{CT}_{\max }=39.8^{\circ} \mathrm{C}$ and $\mathrm{CT}_{\min }=9.6^{\circ} \mathrm{C} ; \mathrm{AT}=20^{\circ} \mathrm{C}, \mathrm{CT}_{\max }=39.8^{\circ} \mathrm{C}$ and $\mathrm{CT}_{\min }=$ $12.8^{\circ} \mathrm{C} ; \mathrm{AT}=25^{\circ} \mathrm{C}, \mathrm{CT}_{\max }=40.4^{\circ} \mathrm{C}$ and $\mathrm{CT}_{\min }=13.1^{\circ} \mathrm{C} ; \mathrm{AT}=30^{\circ} \mathrm{C}, \mathrm{CT}_{\max }=41.5^{\circ} \mathrm{C}$ and $\mathrm{CT}_{\min }$ $=16 \cdot 0^{\circ} \mathrm{C}$. Angular coefficients $(\mathrm{a})$ are indicated next to regression line for $\mathrm{CT}_{\max }$ and $\mathrm{CT} \mathrm{T}_{\min }$.

The percentage of variation between the $\mathrm{CT}_{\max }$ and $\mathrm{CT}_{\min }$ for the 2 groups tested was, for acclimation temperatures of $15,20,25$ and $30^{\circ} \mathrm{C}$, respectively: (CT $\max$ ) 1.3\%; 1.3\%; 2.0\% and 2.2\%; (CT $\min$ ) 2.1\%;3.9\%, 26\% and $11.8 \%$. Apart from these two last values, the two groups used generated very similar results, lending confidence in the specific values obtained.

A direct relationship was also evident between the onset of three other behaviors (motor disorganization, loss of response to stimuli, and respiratory arrest) and the acclimation temperatures (Fig. 2), such as was observed with the critical thermal limits (Fig. 1). It is also clear from figure 2 that the sequence of behaviors is: 1) motor disorganization (Fig. 2a), 2) loss of response to stimuli (Figs 2b and 3) respiratory arrest (Fig. 2c), as the temperature of the water distanced itself from the AT. It is also worth noticing that the inclination of the lines tend to decrease along this sequence, at least for the maximum temperatures (Fig. 2a,b,c). It should be added here that "loss of equilibrium", the variable used for $\mathrm{CT}_{\max }$ and $\mathrm{CT}_{\min }$ determination, occurs approximately at the same time as "loss of response to stimuli".

Animals acclimated to $15^{\circ} \mathrm{C}$ showed reduced movements and remained on the bottom, next to the aerator stone. In the $\mathrm{CT}_{\max }$ determination groups, as temperature was raised, motor activity of the fishes was progressively increased, they started to swim in all directions on the bottom of the aquarium. At $28^{\circ} \mathrm{C}$, movements got reduced again, and operculi movement showed increase in gill ventilation. In the experimental group submitted to temperature decrease from $15^{\circ} \mathrm{C}$, motor activity progressively decreased even further, along with response to stimuli. 

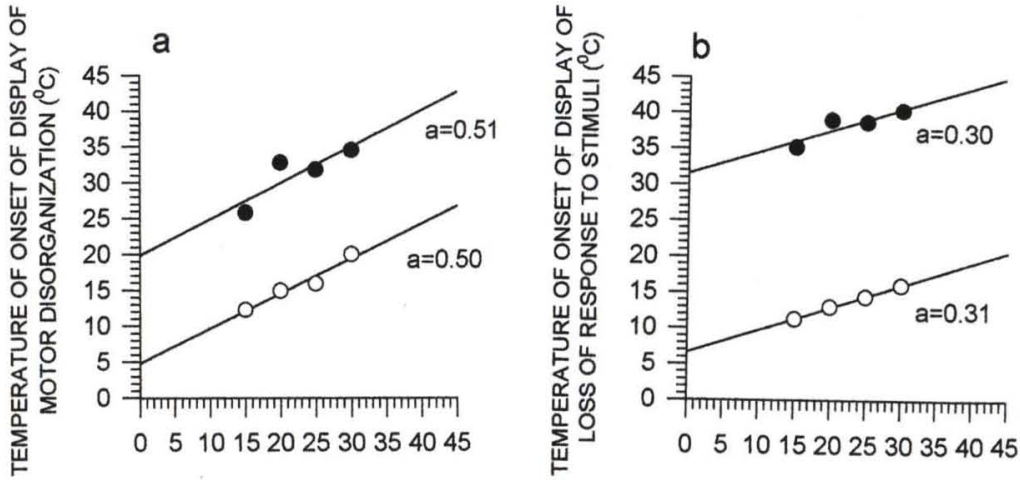

ACCLIMATION TEMPERATURE $\left({ }^{\circ} \mathrm{C}\right)$
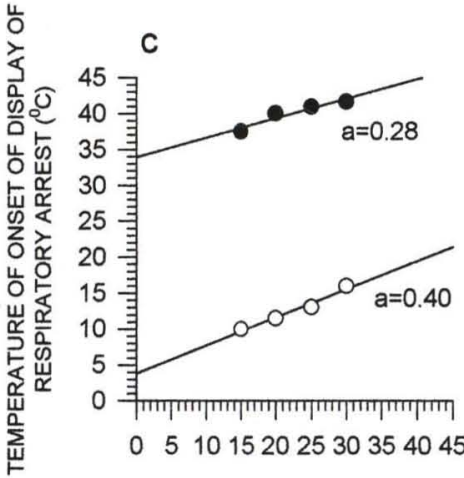

ACCLIMATION TEMPERATURE $\left({ }^{\circ} \mathrm{C}\right)$

Fig. 2. (a) Linear regression between the average temperature of onset of display of motor disorganization with either elevation $\left(\bullet, r^{2}=0.74\right)$ or reduction $\left(0, r^{2}=0.94\right)$ of the temperature of the water and the acclimation temperatures; (b) Linear regression between the average temperature of onset of display of loss of response to stimuli with either elevation $\left(0, r^{2}=0.79\right)$ or reduction $\left(0, r^{2}=0.99\right)$ of the temperature of the water and the acclimation temperature; (c) Linear regression between the average temperature of onset of display of respiratory arrest with either elevation $\left(0, r^{2}=0.90\right)$ or reduction $\left(0, r^{2}=0.96\right)$ of the temperature of the water and the acclimation temperature. Angular coefficients (a) are indicated next to each regression line.

The four groups of fishes acclimated to $20^{\circ} \mathrm{C}$ diplayed normal behavior (freely moving in all directions and feeding normally) during the acclimation period. With temperature increase, their movements were accelerated. Above $30^{\circ} \mathrm{C}$, there were signs of motor disorganization, and increase in gill ventilation was also evident. When the temperature was decreased from $20^{\circ} \mathrm{C}$, and reached $13.5^{\circ} \mathrm{C}$, the fish displayed fast and disorganized movements. At the end of the $\mathrm{CT}_{\min }$ test, at $11^{\circ} \mathrm{C}$, the fishes were basically showing no movement on the bottom of the aquarium.

The four groups of animals acclimated to $25^{\circ} \mathrm{C}$ had normal swimming pattern at the beginning of the tests. Temperature increase, above $29^{\circ} \mathrm{C}$ caused motor 
disorganization along with increased ventilation and movement towards the aerator stone or the surface of the water. Upon temperature reduction, the fish remained next to the bottom of the aquarium, close to the aerator stone and motor activity of the animals decreased at $17^{\circ} \mathrm{C}$. Below $14^{\circ} \mathrm{C}$ they had reduced movements and rarely swam to the surface.

The four groups acclimated to $30^{\circ} \mathrm{C}$ displayed normal swimming pattern during the whole period of acclimation. In the $\mathrm{CT}_{\text {max }}$ test above $32^{\circ} \mathrm{C}$, motor activity became disorganized and the animals displayed fast and erratic movements. They also displayed hyperventilation, went up to the water surface for oxygen and remained close to the aerator stone. In the $\mathrm{CT}_{\min }$ test, below $25^{\circ} \mathrm{C}$, swimming activity was reduced, with the animals remaining close to the bottom at $17^{\circ} \mathrm{C}$.

At the end of the $\mathrm{CT}_{\min }$ test, for all acclimation groups, fish were transferred to an aquarium maintained at $25^{\circ} \mathrm{C}$. After a few seconds, they displayed completely normal swimming pattern again. However, those fish submitted to $\mathrm{CT}_{\max }$ test rarely displayed normal swimming pattern again after transference to aquaria at $25^{\circ} \mathrm{C}$.

\section{DISCUSSION}

Xiphophorus maculatus diplayed a direct relationship between acclimation temperature (AT) and $\mathrm{CT}_{\max }$ or $\mathrm{CT}_{\min }$. In other words, for the highest values of acclimation temperatures $\left(25\right.$ and $\left.30^{\circ} \mathrm{C}\right), \mathrm{CT}_{\max }$ and $\mathrm{CT}_{\min }$ were accordingly higher than the thermal limit values determined for the lower acclimation temperatures ( 15 and $20^{\circ} \mathrm{C}$ ) (Fig. 1). The same relationship was observed for the other behaviors analysed (Fig. 2a,b,c), with high values of linear regression coefficients $\left(\mathrm{r}^{2}\right)$. Platyfish displayed greater capacity of acclimation to higher temperatures, as opposed to lower temperatures. This is clear in figure 1, where it can be seen that the distance between $\mathrm{AT}$ values and $\mathrm{CT}_{\max }$ values is greater than the distance between $\mathrm{AT}$ values and $\mathrm{CT}_{\text {min }}$ values, for all ATs, except $30^{\circ} \mathrm{C}$. The thermal limits for the platyfish display a direct relationship to ATs, but with low values of angular coefficients for the regression lines, well below 1 (Fig. 1). Although AT influences $\mathrm{CT}_{\max }$ and $\mathrm{CT}_{\min }$, this influence is limited by the genetically imposed thermal limits of the species. In other words, ATs exerts some influence on thermal limits, but only to a certain degree. On the other hand, it is important to remark that the experimental results presented here were obtained under laboratory conditions, and thus may not represent the real plasticity of this species in nature.

Nevertheless, laboratory results have indicated that the potential acclimation effect on thermal limits may reflect adaptative mechanisms for tolerance of seasonal alterations in environmental temperature (BARRIONUEVO \& FERNANDES 1995; KELSCH 1996), where temperature variations are fairly smoother than in laboratory situations. Similar results have been reported for other fish species; e.g. fish acclimated to high temperatures are more tolerant to additional temperature increase (CHUNG \& STRAWN 1994; LYYTIKÄINEN et al. 1997). The results obtained here for $X$. maculatus demonstrate clearly its higher capacity to withstand temperature elevation than temperature reduction, which would indeed be expected for a tropical species. Thermal limits and the hability to acclimate to different thermal regimes differ among different species and determine their degree of eurhythermicity, being 
related to their natural environment. Coherently, species exposed naturally to a wide seasonal variation in temperature are very eurythermic and display thermal preferences that are dependent upon the temperature of acclimation, in the case of laboratory experiments (STAUFFER et al. 1985; FERNANDES \& RANTIN 1986a,b; BARRIONUEVO \& FERNANDES 1995). The geographic region that the species inhabits certainly affects its thermal tolerance. Conversely, different populations of a same species that live in different geographical locations may present different tolerance to extreme temperatures. It can thus be generalized that tropical species are commonly sensitive to temperatures below $18^{\circ} \mathrm{C}$ (HUTCHISON 1961; RANTIN 1980; Rietzler et al. 1980; Fernandes \& RANTIN 1986a,b; Chung \& STRAwn 1994; BARRIONUEVO \& FERNANDES 1995; LUTTERSCHMIDT \& HUTCHISON 1997b).

For the determination of thermal limits, two variables are in fact operated simultaneously: temperature itself, and its rate of change, either for elevation or reduction. The rate of temperature change should be constant, and in this work it was of approximately $1{ }^{\circ} \mathrm{C}$ for each eight minutes or $0.125^{\circ} \mathrm{C} / \mathrm{min}$. In other studies reported in the literature, other rates of temperature change have been used. For example, HUTCHISON (1961) and LUTTERSCHMIDT \& HUTCHISON (1997a) have all adopted a rate of $1^{\circ} \mathrm{C} / \mathrm{min}$; LUTTERSCHMIDT \& HUTCHISON (1997b) have adopted a rate ranging from 0.5 to $1.5^{\circ} \mathrm{C} / \mathrm{min}$; RANTIN $(1980)$ has used a rate of $0.25^{\circ} \mathrm{C} / \mathrm{min}$; RIETZLER et al. (1980), FERNANDES \& RANTIN (1986a) and BARRIONUEVO \& FERNANDES (1995) have used a lower rate, of $0.1^{\circ} \mathrm{C} / \mathrm{min}$; KITA et al. (1996) used $0.08^{\circ} \mathrm{C} / \mathrm{min}$; Young \& $\mathrm{CECH}(1996) 0.1^{\circ} \mathrm{C} / \mathrm{min}$ for temperature increase, and $0.08^{\circ} \mathrm{C} / \mathrm{min}$ for temperature decrease; ElLIOTT et al. (1994) have used still lower rates, of $0.03^{\circ} \mathrm{C} / \mathrm{min}$. The rate of temperature variation adopted in the present study fits into the common practice of studies in this field. A lower rate of temperature change results in more accuracy for the determination of the temperatures at which the specific behaviors are observed. However, too low rates of temperature change can lead to thermal acclimation during the experiment itself (HUTCHISON 1961), or to prolonged experiments in which food deprivation may interfere with the results (ELLIOTT \& ELLIOTT 1995).

Searching for trends with respect to thermal limits and both geographical distribution (tropical or temperate) and body size, figure 3 was elaborated, gathering data both from the present study and previous work from the literature. The geographical distribution of a species exerts a strong influence on its thermal limits.Temperate species (full lines) are more tolerant to low temperatures, and display $\mathrm{CT}_{\min }$ values frequently lower than $5^{\circ} \mathrm{C}$. For these species $\mathrm{CT}_{\max }$ values rarely reach $40^{\circ} \mathrm{C}$, a fact which clearly demonstrates their adaptation to their naturally cold climate. On the other hand, tropical species (traced lines) display higher $\mathrm{CT}_{\min }$ values, which indicates that these species are not so tolerant to low temperatures, which are in fact uncommon in tropical areas. $\mathrm{CT}_{\min }$ for tropical species represented in figure 3 rarely reach $5^{\circ} \mathrm{C}$. Conversely, $\mathrm{CT}_{\max }$ values frequently surpassed $40^{\circ} \mathrm{C}$, showing that these animals are resistant to the heat of their natural environment. In short, when temperate and tropical species are compared, tropical species are more heat-resistant but less cold-resistant than temperate species. X. maculatus presented results compatible with the other tropical species 
displayed in figure 3 , as would be expected. Another parameter considered in figure 3 was the average size range of the animals studied. It was not possible to detect any trend with respect to animal size and thermal limits, at least from the data plotted.

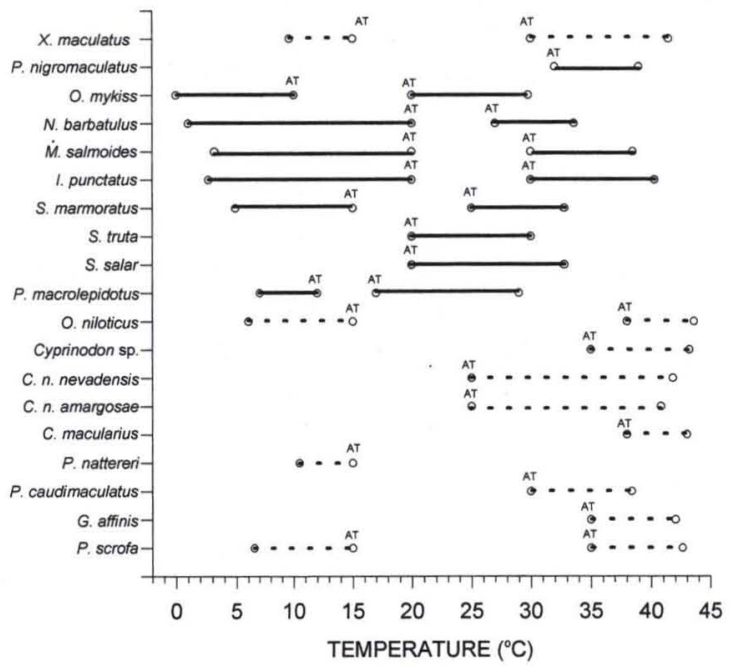

Fig. 3. Acclimation temperature (AT), $C T_{\max }$ values to the right (-- -and - ) and $C T_{\min }$ values to the left (- - - and - ) for 18 species of fishes classified according to size $(+\leq 10 \mathrm{~cm} ; 10<++$ $\leq 20 \mathrm{~cm} ;+++>20 \mathrm{~cm}$ ), and general geographic distribution (tropical: - - -; temperate: -). Tropical species: (1) Prochilodus scrofa (Curimbatá) (BARRIONUEVo \& FERNANDES 1995) +++; (2) Gambusis affinis (mosquito-fish) (GERKING et al. 1975) ++; (3) Phalloceros caudimaculatus (guppy) (RIETZLER et al. 1980) ++; (4) Pygocentrus nattereri (red-bellied piranha) (BENNETT et al. 1997) ++; (5) Cyprinodon macularius (desert pupfish) (LOWE \& HEAT 1969; NELSON 1994) +; (6) Cyprinodon nevadensis amargosae (desert pupfish) (BROWN \& FELDMETH 1971; NELSON 1994) +; (7) Cyprinodon nevadensis nevadensis (desert pupfish) (BROWN \& FELDMETH 1971; Nelson 1994) +; (8) Cyprinodon sp. (pupfish) (OTTO \& Gerking 1973; Nelson 1994) +; (9) Oreochromis niloticus (tilapia) (FERNANDES \& RANTIN 1986a) +. Temperate species: (10) Pogonichtys macrolepidotus (splittail) (Young \& CECH 1996) +++; (11) Salmo salar (atlantic salmon) (ELLIOTT \& ELLIOTT 1995) +++; (12) Salmo trutta (brown trout) (ELLIOTT \& ELLIOTT 1995) +++; (13) Sebastiscus marmoratus (rockfish) (KITA et al. 1996) ++; (14) Ictalurus punctatus (channel catfish) (CURRIE et al. 1998) +; (15) Micropterus salmoides (largemouth bass), (CURRIE et al. 1998) +; (16) Noemacheilus barbatulus (stone loach) (ELLIOT et al. 1994) +; (17) Oncorhynchus mykiss (rainbow trout) (CURRIE et al. 1998) + (young); (18) Pomoxis nigromaculatus (black crappie) (BAKER \& HeIDINGER 1996) +. Present study (tropical fish): (19) Xiphophorus maculatus (platyfish) +. Observation: when more than one acclimation temperature was used in the studies reported here, both for $C T_{\max }$ and $C T_{\min }$, only the most extreme values were displayed for reasons of clarity of the trends present.

Thermal limits for the platyfish can be compared with those values obtained for native species. The results obtained here were slightly different from those determined for the curimbatá (Prochilodus scrofa Steindachner, 1881), a freshwater species found in Southeastern Brazil (BARRIONUEVO \& FERNANDES 1995). For the same acclimation temperature used for $X$. maculatus, the results showed that the 
curimbatá is more cold-resistant than the platyfish, presenting a lower $\mathrm{CT}_{\min }$ value, a result compatible with the distribution of the curimbatá in cooler regions of Brazil. RANTIN (1980) has determined lethal temperatures for the acará (Geophagus brasiliensis Quoy \& Gaimard, 1824), a species found along the whole country of Brazil, from the Amazon Basin down to the Southernmost State of the country, Rio Grande do Sul. Inferior and superior lethal temperatures for the acará were similar to temperatures of respiratory arrest for $X$. maculatus, which is coherent with the fact that both species are tropical and distributed over warm/hot regions. Investigations of physiological limits for the animals are relevant to allow the understanding of the distribution of the species and their adaptation to the environment.

In conclusion, $X$. maculatus is a tropical species which better withstands high than low temperatures, as its $\mathrm{CT}_{\min }$ values were not lower than $9.5^{\circ} \mathrm{C}$ and its $\mathrm{CT}_{\max }$ values were over $40^{\circ} \mathrm{C}$. The results obtained through the present study showed that the platyfish does not adapt completely to the temperatures prevalent in Southern Brazil during winter (less than $10^{\circ} \mathrm{C}$ are commonly recorded). X. maculatus can thus be better adapted to warmer regions, where average annual temperature is around $20-25^{\circ} \mathrm{C}$, a finding coherent with the average temperature of its natural habitat in River Papaloapan in Mexico $\left(23.8^{\circ} \mathrm{C}\right.$, GoHM 1972). It is basically impossible to grow $X$. maculatus in the natural environment of Southern Brazil and, in aquaria, it should be maintained with other tropical species, under mild temperatures.

ACKNOWLEDGMENTS. The authors wish to thank Mr. Luiz Fernando Peraceta, electronic technician of the Setor de Ciências Biológicas (UFPR), for the assembly of the acclimation chamber, and the Post-Graduation course in Physiology of the Departamento de Fisiologia (UFPR) for financial support.

\section{REFERENCES}

BAKER, S.C. \& R.C. Heidinger. 1996. Upper lethal temperature tolerance of fingerling black crappie. Jour. Fish Biol. 48: 1123-1129.

Barrionuevo, W.R. \& M.N. Fernandes. 1995. Critical thermal maxima and minima for curimbatá, Prochilodus scrofa Steindachner, of two different sizes. Aquac. Res. 26: 447-450.

BEnfEY, T.J.; L.E. MCCABE \& P. PEPIN. 1997. Critical thermal maxima of diploid and triploid brook charr, Salvelinus fontinalis. Environ. Biol. Fishes 49: 259-264.

Bennett, W.A.; R.J. Currie; P.F. Whgner \& T.L. Beitinger. 1997. Cold tolerance and potential overwintering of the red-bellied piranha Pygocentrus nattereri in the United States. Trans. Amer.

Fish. Soc. 126: 841-849.

BRETT, J.R. 1956. Some principles in the thermal requirements of fishes. Quart. Rev. Biol. 31 (2): 75-87.

BRown, J.H. \& C.R. Feldmeth. 1971. Evolution in constant and flutuating environments: thermal tolerance of desert pupfish (Cyprinodon). Evolution 25: 390-398.

ChUNG, K.S. \& K. StRAwn. 1994. What factors influence the thermal tolerance of estuarine animals? Interpretation of multiple regression analyses. Rev. Biol. Trop. 42 (1-2): 365-370.

COWLES, R.B. \& C.M. BogerT. 1944. A preliminary study of thermal requirements of desert reptiles. Bull. Amer. Mus. Nat. Hist. 83: 265-296.

CURRIE, R.J.; W.A. BENNETT \& T.L. Beitinger. 1998. Critical thermal minima and maxima of three freshwater game-fish species acclimated to constant temperatures. Environ. Biol. Fishes. 51: 187-200.

DOUDOROFF, P. 1942. The resistance and acclimatization of marine fishes to temperature changes. I 
Experiments with Girella nigricans (Ayres). Biol. Bull. 83: 219-244.

ElLiotT, J.M. \& J.A. ELLIOTT. 1995. The effect of the rate of temperature increase on the critical thermal maximum for parr of Atlantic salmon and brown trout. Jour. Fish Biol. 47: 917-919.

ElliotT, J.M.; J.A. Elliott \& J.D. Allonby. 1994. The critical thermal limits for the stone loach, Noemacheilus barbatulus, from three populations in north-west England. Freshwater Biol. 32: 593-601.

Evans, D.H. 1993. The Physiology of Fishes. Boca Raton: CRS Series in Marine Science, 592p.

FERNANDES, M.N. \& F.T. RANTIN. 1986a. Lethal temperatures of Oreochromis niloticus (Pisces, Cichlidae). Rev. Brasil. Biol. 46 (3): 589-595.

FERnANDES, M.N. \& F.T. RANTIN. 1986b. Thermal acclimation of teleost Oreochromis niloticus (Pisces, Cichlidae). Rev. Hydrobiol. Trop. 19 (3-4): 163-168.

GERKING, S.D.; T. RATCLIFF \& R.G. OTTO. 1975. Laboratory and field tests of temperature tolerance on Gambusia affinis, the western mosquito-fish. Verh. Intern. Verein. Limnol. 19: 2498-2503.

GoHm, D. 1972. Tropical Fish. London, Hamlyn Publ. Group, $3^{\text {rd }}$ ed., 143p.

Hutchison, V.H. 1961. Critical thermal maxima in salamanders. Physiol. Zool. 34: 92-125.

JoRDan, D.S. 1963. The Genera of Fishes and a Classification of Fishes. Stanford, Stanford Univ. Press, 800p.

KelsCH, S.W. 1996. Temperature selection and performance by bluegills: evidence for selection in response to available power. Trans. Amer. Fish. Soc. 125: 948-955.

Kita, J.; S. Tsuchida \& T. Setoguma. 1996. Temperature preference and tolerance, and oxygen consumption of the marbled rockfish, Sebastiscus marmoratus. Mar. Biol. 125: 467-471.

LOWE, C.H. \& W.G. HEAT. 1969. Behavioural and physiological responses to temperature in desert pupfish Cyprinodon macularius. Physiol. Zool. 42: 53-59.

LUTTERSCHMiDT, W.I. \& V.H. HUTCHISON. 1997a. The critical thermal maximum: data to support the onset of spasms as the definitive end point. Can. Jour. Zool. 75: 1553-1560.

- 1997b. The critical thermal maximum: history and critique. Can. Jour. Zool. 75: 1561-1574.

LYYTIKÄINEN, T.; J. KOSKELA \& I. RISSANEN. 1997. Thermal resistance and upper lethal temperatures of underyearling Lake Inari Arctic charr. Jour. Fish. Biol. 51: 515-525.

Nelson, J.S. 1994. Fishes of the World. New York, John Wiley \& Sons, $3^{\text {rd }}$ ed., 600p.

OTto, R.G. \& S.D. Gerking. 1973. Heat tolerance of the death valley pupfish (genus Cyprinodon). Physiol. Zool. 46: 43-49.

Pough, F.H; J.B. Heiser \& W.N. McFarland. 1996. Vertebrate Life. Upper Saddle River, Prentice Hall, $4^{\text {th }}$ ed., $798 \mathrm{p}$.

RANTIN, F.T. 1980. Temperaturas letais do acará Geophagus brasiliensis (Quoy \& Gaimard, 1824 Pisces, Cichlidae). Bol. Fisiol. Animal 4: 9-33.

Rietzler, A.C.; F.T. Rantin \& F. Glens. 1980. Studies on the critical thermal maximum of the guppy Phalloceros caudimaculatus (Hensel, 1826) (Pisces, Poecillidae). Bol. Fisiol. Animal 5: 19-27.

Schmidt-Nielsen, K. 1997. Animal Physiology: Adaptation and Environment. Cambridge, Cambridge Univ. Press, $5^{\text {th }}$ ed., $607 \mathrm{p}$.

StAufFer JR., J.R.; C.H. Hocutt \& W.F. GoodFEllow. 1985. Effects of sex and maturity on preferred temperatures: A proximate factor for increased survival of young Poecilia latipinna? Arch. Hydrobiol. 103 (1): 129-132.

YounG, P.S. \& J.J. CECH. 1996. Environmental tolerances and requirements of splittail. Trans. Amer. Fish. Soc. 125: 664-678.

Recebido em 18.V.2000; aceito em 19.VI.2001. 